\title{
Synthesis, Spectral Studies of Binuclear Divalent Metal Chelates Derived from Benzofuron-2-carbo- hydrazide and 1-Chloro-4-isothiocyanatobenzene
}

\author{
GAJENDRA KUMAR ${ }^{*}$ and VIDHI SINGH \\ Chemical Science Laboratory, Bhagwant Institute of Technology, \\ Muzaffarnagar-251315 (U.P), India \\ gaj.chem@gmail.com
}

Received 7 December 2015 / Accepted 18 December 2015

\begin{abstract}
The M(II) complex of benzofuron-2-carbohydrazide, 1-chloro-4-isothiocyanatobenzene and nitrophenol (2-nitrophenol, 2,3- dinitropheno, 2,3,4- trinitrophenol) with transition metal ion e.g. $\mathrm{Cu}(\mathrm{II}), \mathrm{Ni}(\mathrm{II})$ and $\mathrm{Co}$ (II) were prepared. All the complex have structure formula $\left[\mathrm{Cu}_{2}\left(\mathrm{C}_{56} \mathrm{H}_{40} \mathrm{~N}_{10} \mathrm{Cl}_{2} \mathrm{O}_{16} \mathrm{~S}_{2}\right)\right], \quad\left[\mathrm{Ni}_{2}\left(\mathrm{C}_{56} \mathrm{H}_{40} \mathrm{~N}_{10} \mathrm{Cl}_{2} \mathrm{O}_{16} \mathrm{~S}_{2}\right)\right], \quad\left[\mathrm{Co}_{2}\left(\mathrm{C}_{56} \mathrm{H}_{40} \mathrm{~N}_{10} \mathrm{Cl}_{2} \mathrm{O}_{16} \mathrm{~S}_{2}\right)\right], \quad\left[\mathrm{Cu}_{2}\left(\mathrm{C}_{56} \mathrm{H}_{36} \mathrm{~N}_{14}\right.\right.$ $\left.\left.\mathrm{Cl}_{2} \mathrm{O}_{24} \mathrm{~S}_{2}\right)\right], \quad\left[\mathrm{Ni}_{2}\left(\mathrm{C}_{56} \mathrm{H}_{36} \mathrm{~N}_{14} \mathrm{Cl}_{2} \mathrm{O}_{24} \mathrm{~S}_{2}\right)\right], \quad\left[\mathrm{Co}_{2}\left(\mathrm{C}_{56} \mathrm{H}_{36} \mathrm{~N}_{14} \mathrm{Cl}_{2} \mathrm{O}_{24} \mathrm{~S}_{2}\right)\right], \quad\left[\mathrm{Cu}_{2}\left(\mathrm{C}_{56} \mathrm{H}_{32} \mathrm{~N}_{18} \mathrm{Cl}_{2} \mathrm{O}_{32} \mathrm{~S}_{2}\right)\right]$, $\left[\mathrm{Ni}_{2}\left(\mathrm{C}_{56} \mathrm{H}_{32} \mathrm{~N}_{18} \mathrm{Cl}_{2} \mathrm{O}_{32} \mathrm{~S}_{2}\right)\right]$ and $\left[\mathrm{Co}_{2}\left(\mathrm{C}_{56} \mathrm{H}_{32} \mathrm{~N}_{18} \mathrm{Cl}_{2} \mathrm{O}_{32} \mathrm{~S}_{2}\right)\right]$ characterized by the several analytical techniques including elemental analysis (C.H.N.), molar conductance measurements, magnetic measurements, electronic, FAB mass, IR, ${ }^{1} \mathrm{H}$ NMR and ${ }^{13} \mathrm{C}$ NMR spectral studies. Based on these studies six coordinated octahedral geometry for all the complexes was proposed.
\end{abstract}

Keyword: Divalent metal complex, Benzofuron-2-carbohydrazide, 1-Chloro-4-isothiocyanatobenzene, Spectroscopic study

\section{Introduction}

The introduction of $\mathrm{S}, \mathrm{O}$ and $\mathrm{N}$ atom containing group in the organic molecules have often resulted into the important change in the behavior towards metal ions. Organic heterocyclic compounds are one of the important classes of ligand which have shown immense importance in our life. Several heterocyclic compounds are often used as chemotherapeutic agents and drug copolymers. A large number of hetero cyclic compounds containing N, S or $\mathrm{O}$ as hetero atom in the ring are known to form complexes with transition metal ions. These complexes have shown importance in the field of catalysis, medicine, analytical chemistry and biological activity. The formation and characterization of azomethines complexes was done by Schiff ${ }^{1}$, who reported the formation of, 1:2 metal: ligand ratio, copper complexes derived from $\mathrm{N}$-aryl salicyldimine but the first report on the metal complexes of azomethine was much before when Ettling prepared a $\mathrm{Cu}$ (II) complex with salicyladimine ${ }^{2}$ which was a crystalline solid of dark green colour. But the work in this field has gained momentum since the last four decades only. In 1965 Chaston and co-workers ${ }^{3}$ reported the preparation of 
azonmethine ligand by the condensation of benzoylacetone and 1,2-diaminoethane and its complexes with transition metals. Lindoy and co-workers ${ }^{4}$ reported a number of azomethine complexes of various metals with methyl thioquinoline. A number of publications appeared about the lanthanide ion complexes with azomethines derived from bis-salicylaldehyde and $o$-phenylenediamine $e^{5}$ and $p$-dimethylaminobenzaldehyde and benzidine ${ }^{6}$. A number of M(II) complexes with azomethine have been reported by various workers ${ }^{7-13}$. Metal complexes of azomethine ligand derived from pivaloylacetone and 1,2-diaminoethane have also been reported $^{14}$. Five and six-coordinated $\mathrm{Co}(\mathrm{II}), \mathrm{Ni}(\mathrm{II}), \mathrm{Cu}(\mathrm{II})$ and $\mathrm{Zn}(\mathrm{II})$ complexes of the pentadentate azomethine ligands. $N, N$-Bis [(2-hydroxy-5- $Y$-phenyl) phenylmethylene-4azoheptane-1,7-diamine (where $\mathrm{Y}=\mathrm{Chloro}$ or methyl)] and $\mathrm{N}$ - $N$-Bis [5-chloro-2-hydroxyphenyl) phenylmethylene-4-thioheptane-1,7-diamine have been synthesized and characterized by Boge and co-workers ${ }^{15}$. Azomethine formed in the condensation reactions between unsymmetrical $\beta$-diketones and 1,2-diamino ethane and their transition complexes have also been reported in the literature ${ }^{16}$. The azomethine derived from bis-vanillin and $o$-phenylenediamine and their lanthanide complexes have also been reported in the literature ${ }^{17}$. Tripathy and co-workers prepared azomethines viz. bis-salicylaldehyde ethylene diamine and bis-o-hydroxyacetophenone ethylenediamine, and their transition metal complexes ${ }^{18}$. The aim of the present study is to prepare and characterized divalent bimolecular metal ion complexes derived from benzofuron-2-carbohydrazide and 1-chloro-4-isothiocyanatobenzene.

\section{Experimental}

The entire chemicals used, were of the analytical grade, benzofuran-2-carbohydrazide, p-chlorophenyl isothiocyanate, 2, nitrophenol, 2, 3 dinitrophenol, 2, 3, 4, trinitrophenol, procured from s.d.-fine. Metal salts were purchased from Merck.

\section{Benzofuro- 2-carboxy- [4'-chlorophenyl] thiosemicarbazide}

Benzofuran-2-carbohydrazide (4.58 g, $0.026 \mathrm{~mol})$ was dissolved in ethanol and this solution was added 1-chloro-4-isothiocyanatobenzene $(4.41 \mathrm{~g}, 0.026 \mathrm{~mol})$ in a 1:1 molar ratio containing few drop of concentrated $\mathrm{HCl}$. The solution was refluxed for $3 \mathrm{~h}$. The cream crystalline product which formed was filtered off under vacuum and recrystallized from ethanol (Scheme 1).

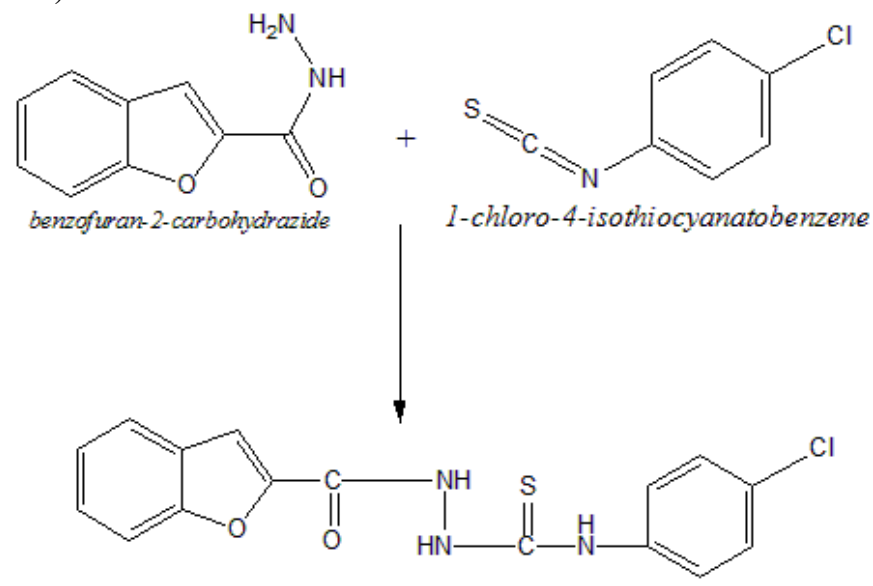

Benzofuro-2-carboxy-[4'-chlorophenyl] thiosemicarbazide

Scheme 1. Synthesis of ligand 
Synthesis of the $\mathrm{Cu}(\mathrm{II}), \mathrm{Ni}(\mathrm{II})$ and $\mathrm{Co}(\mathrm{II})$ complexes

A solution of divalent metal salt $(2.0 \mathrm{~mol})$ in methanol $(12 \mathrm{~mL})$ was added to a hot solution $\left(75{ }^{\circ} \mathrm{C}\right)$ of benzofuro- 2-carboxy- [4'-chlorophenyl] thiosemicarbazide ligand $(2.0 \mathrm{~mol})$ and nitrophenol $(4.0 \mathrm{~mol})$ in ethanol $(28 \mathrm{~mL})$ and the reaction mixture was refluxed for $8 \mathrm{~h}$. The solution was concentrated under vacuum. The precipitate was filtered off, washed with methanol and dried under vacuum over anhydrous $\mathrm{CaCl}_{2}$ (68-75\% yield) (Scheme 2 ).

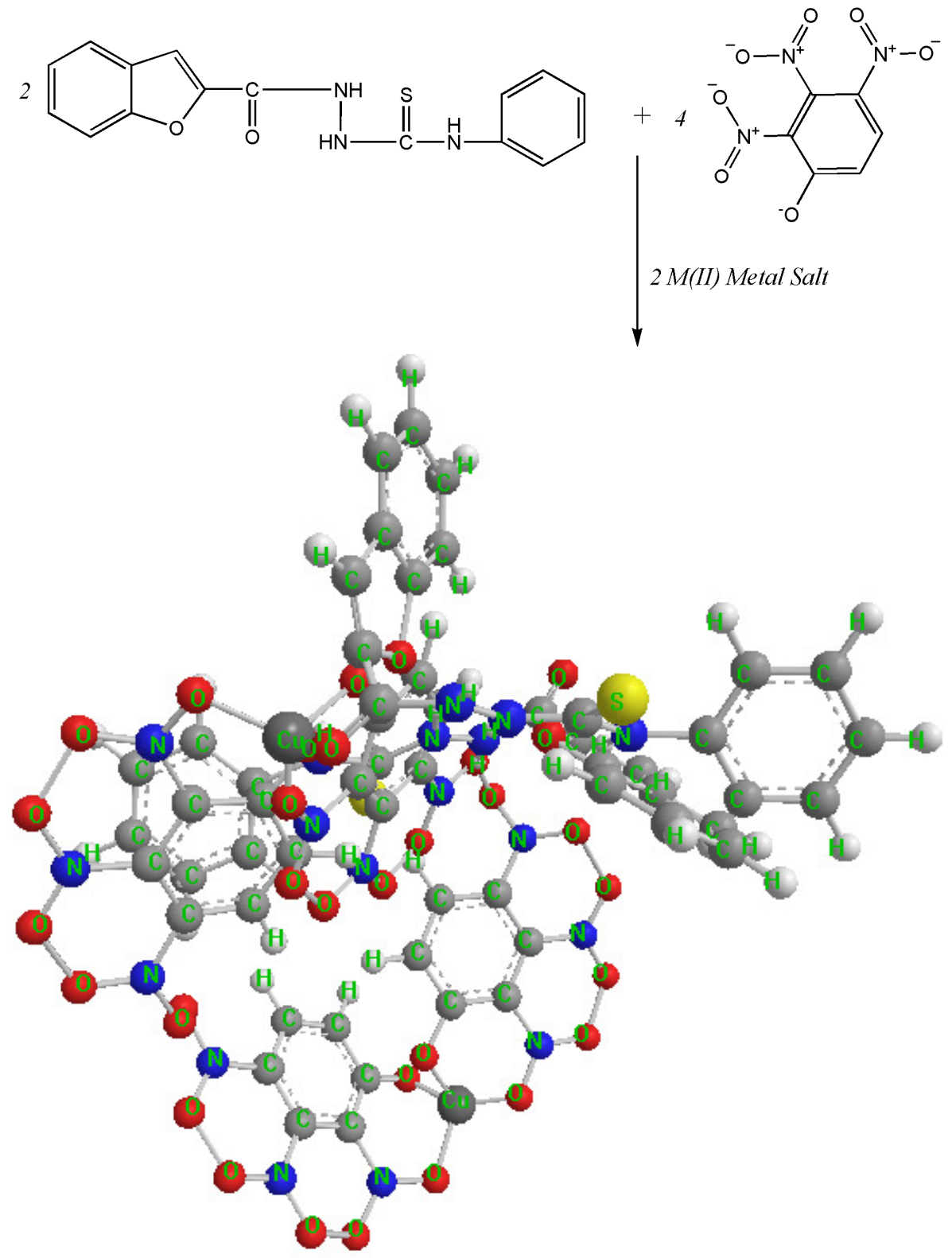

Scheme 2. Synthesis of divalent bimolecular metal complex 


\section{Results and Discussion}

\section{Mass spectra}

The FAB mass spectra of $\mathrm{Cu}(\mathrm{II}), \mathrm{Ni}(\mathrm{II})$ and $\mathrm{Co}(\mathrm{II})$ Schiff base complexes have been recorded (Table 1). The molecular ion $\left(\mathrm{M}^{+}\right)$peaks obtained from various complexes are as follows: (1) $m / z=444.80 \mathrm{C}_{16} \mathrm{H}_{12} \mathrm{~N}_{3} \mathrm{ClO}_{2} \mathrm{~S}$, (2) $\mathrm{m} / z=1370.10 \quad\left[\mathrm{Cu}_{2}\left(\mathrm{C}_{56} \mathrm{H}_{40} \mathrm{~N}_{10}\right.\right.$ $\left.\left.\mathrm{Cl}_{2} \mathrm{O}_{16} \mathrm{~S}_{2}\right)\right]$ (complex 1), (3) $\mathrm{m} / \mathrm{z}=1360.4\left[\mathrm{Ni}_{2}\left(\mathrm{C}_{56} \mathrm{H}_{40} \mathrm{~N}_{10} \mathrm{Cl}_{2} \mathrm{O}_{16} \mathrm{~S}_{2}\right)\right]$ (complex 2), (4) $m / z=1360.88\left[\mathrm{Co}_{2}\left(\mathrm{C}_{56} \mathrm{H}_{40} \mathrm{~N}_{10} \mathrm{Cl}_{2} \mathrm{O}_{16} \mathrm{~S}_{2}\right)\right]$ (complex 3), (5) $\mathrm{m} / z=1550.09\left[\mathrm{Cu}_{2}\left(\mathrm{C}_{56} \mathrm{H}_{36} \mathrm{~N}_{14}\right.\right.$ $\left.\left.\mathrm{Cl}_{2} \mathrm{O}_{24} \mathrm{~S}_{2}\right)\right]$ (complex 4), (6) $\mathrm{m} / z=1540.3\left[\mathrm{Ni}_{2}\left(\mathrm{C}_{56} \mathrm{H}_{36} \mathrm{~N}_{14} \mathrm{Cl}_{2} \mathrm{O}_{24} \mathrm{~S}_{2}\right)\right]$ (complex 5), (7) $m / z=1540.8\left[\mathrm{Co}_{2}\left(\mathrm{C}_{56} \mathrm{H}_{36} \mathrm{~N}_{14} \mathrm{Cl}_{2} \mathrm{O}_{24} \mathrm{~S}_{2}\right)\right]$ (complex 6), (8) $\mathrm{m} / z=1730.08\left[\mathrm{Cu}_{2}\left(\mathrm{C}_{56} \mathrm{H}_{32} \mathrm{~N}_{18}\right.\right.$ $\mathrm{Cl}_{2} \mathrm{O}_{32} \mathrm{~S}_{2}$ )] (complex 7), (9) $\mathrm{m} / \mathrm{z}=1720.3\left[\mathrm{Ni}_{2}\left(\mathrm{C}_{56} \mathrm{H}_{32} \mathrm{~N}_{18} \mathrm{Cl}_{2} \mathrm{O}_{32} \mathrm{~S}_{2}\right.\right.$ )] (complex 8), (10) $m / z=1720.8 \quad\left[\mathrm{Co}_{2}\left(\mathrm{C}_{56} \mathrm{H}_{32} \mathrm{~N}_{18} \mathrm{Cl}_{2} \mathrm{O}_{32} \mathrm{~S}_{2}\right)\right]$ (complex 9). In addition to the peaks due to the molecular ion, the spectra exhibit peaks assignable to various fragments arising from the thermal cleavage of the complexes. The peak intensity gives an idea of the stability of the fragments.

\section{IR spectra}

The IR spectral of the Schiff base ligand show a $v(\mathrm{C}=\mathrm{N})$ peak at $1610 \mathrm{~cm}^{-1}$ and a medium intensity absorption band at $3180 \mathrm{~cm}^{-1}$ which is attributed to the $r(\mathrm{~N}-\mathrm{H})$ stretching vibration. The high intensity band at $1613-1632 \mathrm{~cm}^{-1}$ which is attributed to the $v(\mathrm{C}=\mathrm{N})$ vibration. The bands present in the range $\sim 3020-3060 \mathrm{~cm}^{-1}$ may be assigned due to $v(\mathrm{C}-\mathrm{H})$ stretching vibrations of aromatic moiety ${ }^{19}$. The various absorption band in the range $\sim 1455$ $1570 \mathrm{~cm}^{-1}$ may be assigned due to $v(\mathrm{C}=\mathrm{C})$ aromatic stretching vibrations of the aromatic ring $^{20}$. Another strong band at $1690-1735 \mathrm{~cm}^{-1}$ indicate the presence of $v(\mathrm{C}=\mathrm{O})$. The absorption of O-O and C-O stretching modes is in the range $900-1000 \mathrm{~cm}^{-1}$. Their strong appearance is an indication of strong mixing with the $\mathrm{C}-\mathrm{O}$ modes comparison of the calculated peaks and the measured ones in this region shows that the theoretical spectrum is red shifted relative to the experimental data ${ }^{21}$. The IR spectra of nitrato complexes exhibits bands at $1290-1310 \mathrm{~cm}^{-1}, 1050-1065 \mathrm{~cm}^{-1}$ and $1435-1450 \mathrm{~cm}^{-1}$ which can be assigned to $\mathrm{NO}_{2}$ symmetric stretching $\left(v_{1}\right)$; N-O stretching $\left(v_{2}\right) ; \mathrm{NO}_{2}$ asymmetric stretching $\left(v_{5}\right)$ and out of plane rocking, respectively. IR absorption band $\sim 1355-1360 \mathrm{~cm}^{-1}$ assigned the uncoordinated nitro group. The far infrared spectra show bands in the region $420-450 \mathrm{~cm}^{-1}$ corresponding to $r(\mathrm{M}-\mathrm{N})$ vibration ${ }^{22-24}$. The presence of bands in all complexes in the region $420-450 \mathrm{~cm}^{-1}$ originate from (M-N) azomethine vibrational mode and identify coordination of azomethine nitrogen ${ }^{25}$. The bands present in the region $235-260 \mathrm{~cm}^{-1}$ in all the nitrato complexes are assignable to $v(\mathrm{M}-\mathrm{O})$ stretching vibration ${ }^{22,23}$.

\section{${ }^{1} H N M R$}

A survey of literature reveals that Schiff base have characterized by ${ }^{1} \mathrm{H}$ NMR and ${ }^{13} \mathrm{C}$ NMR spectra to ensure ligand structure and purity in $\mathrm{d}_{6}$-dimethylsulfoxide (DMSO- $\mathrm{d}_{6}$ ) solution using $\mathrm{Me}_{4} \mathrm{Si}$ (TMS) as internal standard. The ${ }^{1} \mathrm{H}$ NMR spectra of benzofuro- 2carboxy-[4'-chlorophenyl] thiosemicarbazide was recorded. The ${ }^{1} \mathrm{H}$ NMR spectra of the ligand shows broad signal at 9.4-12.1 ppm due to the presence of $-\mathrm{NH}^{26}$ and 2.1-2.8 ppm due to the $-\mathrm{CH}_{2}-$ (cyclic) $)^{27}$. The multiplets in the region 6.54-8.76 ppm may be assigned to aromatic proton ${ }^{28,29} .{ }^{13} \mathrm{C}$ NMR of the Schiff base ligand, the signal appeared in the region 111.6-158.4 are assigned to aromatic carbon. The signal at 172.8-165.6 ppm are due to $\mathrm{C}=\mathrm{O}^{27}$. 
Table 1. FAB mass spectral data of the divalent bimolecular $\mathrm{Cu}(\mathrm{II}), \mathrm{Ni}(\mathrm{I})$ and $\mathrm{Co}(\mathrm{II})$ metal complexes

\begin{tabular}{cccc}
\hline Complexes & Mol. wt. & $\begin{array}{c}\text { Molecular ion } \\
\text { peak [M] }\end{array}$ & Important peak due to complex fragmentation \\
\hline $\mathrm{C}_{16} \mathrm{H}_{12} \mathrm{~N}_{3} \mathrm{ClO}_{2} \mathrm{~S}$ & 445.8 & 444.8 & $92.1,117.1,194.2,219.02,310.3$ \\
{$\left[\mathrm{Cu}_{2}\left(\mathrm{C}_{56} \mathrm{H}_{40} \mathrm{~N}_{10} \mathrm{Cl}_{2} \mathrm{O}_{16} \mathrm{~S}_{2}\right)\right]$} & 1371.1 & 1370.1 & $92.1,117.1,119.2,138.1,194.2,219.02,276.2,310.3,927.34,1300.2,1335.6$ \\
{$\left[\mathrm{Ni}_{2}\left(\mathrm{C}_{56} \mathrm{H}_{40} \mathrm{~N}_{10} \mathrm{Cl}_{2} \mathrm{O}_{16} \mathrm{~S}_{2}\right)\right]$} & 1361.4 & 1360.4 & $92.1,117.1,119.2,138.1,194.2,219.02,276.2,310.3,922.4,1290.5,1325.9$ \\
{$\left[\mathrm{Co}_{2}\left(\mathrm{C}_{56} \mathrm{H}_{40} \mathrm{~N}_{10} \mathrm{Cl}_{2} \mathrm{O}_{16} \mathrm{~S}_{2}\right)\right]$} & 1361.88 & 1360.88 & $92.1,117.1,119.2,138.1,194.2,219.02,276.2,310.3,922.7,1290.9,1326.4$ \\
{$\left[\mathrm{Cu}_{2}\left(\mathrm{C}_{56} \mathrm{H}_{36} \mathrm{~N}_{14} \mathrm{Cl}_{2} \mathrm{O}_{24} \mathrm{~S}_{2}\right)\right]$} & 1551.09 & 1550.09 & $92.1,117.1,119.2,183.1,194.2,219.0,310.3,366.0,1111.3,1481.0,1515.6$ \\
{$\left[\mathrm{Ni}_{2}\left(\mathrm{C}_{56} \mathrm{H}_{36} \mathrm{~N}_{14} \mathrm{Cl}_{2} \mathrm{O}_{24} \mathrm{~S}_{2}\right)\right]$} & 1541.3 & 1540.3 & $92.1,117.1,119.2,183.1,194.2,219.0,310.3,366.0,1102.4,1471.5,1505.9$ \\
{$\left[\mathrm{Co}_{2}\left(\mathrm{C}_{56} \mathrm{H}_{36} \mathrm{~N}_{14} \mathrm{Cl}_{2} \mathrm{O}_{24} \mathrm{~S}_{2}\right)\right]$} & 1541.8 & 1540.8 & $92.1,117.1,119.2,183.1,194.2,219.0,310.3,366.0,1102.7,1471.9,1506.4$ \\
{$\left[\mathrm{Cu}_{2}\left(\mathrm{C}_{56} \mathrm{H}_{32} \mathrm{~N}_{18} \mathrm{Cl}_{2} \mathrm{O}_{32} \mathrm{~S}_{2}\right)\right]$} & 1731.08 & 1730.08 & $92.1,117.1,119.2,194.2,219.0,238.1,310.3,456.2,1287.3,1661.1,1695.6$ \\
{$\left[\mathrm{Ni}_{2}\left(\mathrm{C}_{56} \mathrm{H}_{32} \mathrm{~N}_{18} \mathrm{Cl}_{2} \mathrm{O}_{32} \mathrm{~S}_{2}\right)\right]$} & 1721.3 & 1720.3 & $92.1,117.1,119.2,194.2,219.0,238.1,310.3,456.2,1282.4,1651.4,1685.9$ \\
{$\left[\mathrm{Co}_{2}\left(\mathrm{C}_{56} \mathrm{H}_{32} \mathrm{~N}_{18} \mathrm{Cl}_{2} \mathrm{O}_{32} \mathrm{~S}_{2}\right)\right]$} & 1721.8 & 1720.8 & $92.1,117.1,119.2,194.2,219.0,238.1,310.3,456.2,1282.7,1651.9,1685.4$ \\
\hline
\end{tabular}

Table 2. Analytical data of the divalent bimolecular $\mathrm{Cu}(\mathrm{II}), \mathrm{Ni}(\mathrm{I})$ and $\mathrm{Co}(\mathrm{II})$ metal complexes

\begin{tabular}{|c|c|c|c|c|c|c|c|c|}
\hline Complex & $\begin{array}{l}\text { Mol. } \\
\text { mass }\end{array}$ & $\mathrm{C}$ & $\mathrm{H}$ & $\mathrm{N}$ & M & Colour & $\begin{array}{c}\text { Yield } \\
\%\end{array}$ & $\begin{array}{c}\text { Conductanc } \\
\Lambda_{\mathrm{M}}\end{array}$ \\
\hline $\mathrm{C}_{16} \mathrm{H}_{12} \mathrm{~N}_{3} \mathrm{ClO}_{2} \mathrm{~S}$ & 345.80 & $55.57(55.55)$ & $3.50(3.48)$ & $12.15(12.17)$ & & & & \\
\hline$\left[\mathrm{Cu}_{2}\left(\mathrm{C}_{56} \mathrm{H}_{40} \mathrm{~N}_{10} \mathrm{Cl}_{2} \mathrm{O}_{16} \mathrm{~S}_{2}\right)\right]$ & 1371.10 & $49.06(49.02)$ & $2.94(2.88)$ & $10.22(10.02)$ & $9.27(2.32)$ & Orange & 71 & $72 \Omega^{-1}$ \\
\hline$\left[\mathrm{Ni}_{2}\left(\mathrm{C}_{56} \mathrm{H}_{40} \mathrm{~N}_{10} \mathrm{Cl}_{2} \mathrm{O}_{16} \mathrm{~S}_{2}\right)\right]$ & 1361.40 & $49.41(49.35)$ & $2.96(2.85)$ & $10.29(10.25)$ & $8.62(8.60)$ & Orange & 78 & $09 \Omega^{-1}$ \\
\hline$\left[\mathrm{Co}_{2}\left(\mathrm{C}_{56} \mathrm{H}_{40} \mathrm{~N}_{10} \mathrm{Cl}_{2} \mathrm{O}_{16} \mathrm{~S}_{2}\right)\right]$ & 1361.88 & $49.39(49.35)$ & $2.96(2.99)$ & $10.28(12.35)$ & $8.65(8.61)$ & Light Yellow & 75 & $15 \Omega^{-1}$ \\
\hline$\left[\mathrm{Cu}_{2}\left(\mathrm{C}_{56} \mathrm{H}_{36} \mathrm{~N}_{14} \mathrm{Cl}_{2} \mathrm{O}_{24} \mathrm{~S}_{2}\right)\right]$ & 1551.09 & $43.36(43.38)$ & $2.34(2.42)$ & $12.64(12.94)$ & $8.19(8.25)$ & Brown & 73 & $74 \Omega^{-1}$ \\
\hline$\left[\mathrm{Ni}_{2}\left(\mathrm{C}_{56} \mathrm{H}_{36} \mathrm{~N}_{14} \mathrm{Cl}_{2} \mathrm{O}_{24} \mathrm{~S}_{2}\right)\right]$ & 1541.39 & $43.64(43.66)$ & $2.35(2.40)$ & $12.72(12.71)$ & $7.62(7.66)$ & Gray & 72 & $11 \Omega^{-1}$ \\
\hline$\left[\mathrm{Co}_{2}\left(\mathrm{C}_{56} \mathrm{H}_{36} \mathrm{~N}_{14} \mathrm{Cl}_{2} \mathrm{O}_{24} \mathrm{~S}_{2}\right)\right]$ & 1541.87 & $43.62(43.74)$ & $2.35(2.33)$ & $12.72(12.86)$ & $7.64(7.68)$ & Light gray & 77 & $16 \Omega^{-1}$ \\
\hline$\left[\mathrm{Cu}_{2}\left(\mathrm{C}_{56} \mathrm{H}_{32} \mathrm{~N}_{18} \mathrm{Cl}_{2} \mathrm{O}_{32} \mathrm{~S}_{2}\right)\right]$ & 1731.08 & $38.85(38.80)$ & $1.86(1.85)$ & $14.56(14.58)$ & $7.34(7.36)$ & Light Yellow & 75 & $79 \Omega^{-1}$ \\
\hline$\left[\mathrm{Ni}_{2}\left(\mathrm{C}_{56} \mathrm{H}_{32} \mathrm{~N}_{18} \mathrm{Cl}_{2} \mathrm{O}_{32} \mathrm{~S}_{2}\right)\right]$ & 1721.38 & $39.07(39.00)$ & $1.87(1.84)$ & $14.65(14.68)$ & $6.82(6.85)$ & Reddish & 74 & $12 \Omega^{-1}$ \\
\hline$\left[\mathrm{Co}_{2}\left(\mathrm{C}_{56} \mathrm{H}_{32} \mathrm{~N}_{18} \mathrm{Cl}_{2} \mathrm{O}_{32} \mathrm{~S}_{2}\right)\right]$ & 1721.86 & $39.06(39.17)$ & $1.87(1.82)$ & $14.64(14.72)$ & $6.85(6.88)$ & Light Yellow & 76 & $18 \Omega^{-1}$ \\
\hline
\end{tabular}




\section{Magnetic, electronic and electron spin resonance spectral studies}

In order to obtain information concerning the stereochemistry of metal ion, the ESR spectrum of this complex is of axial shape with $g_{\|}>g_{\perp}$ characteristic of complexes with ${ }^{2} \mathrm{~B}_{1(\mathrm{dx}-\mathrm{y})}^{2}$ ground state. The average $g$ values were calculated according to the equation $g_{\mathrm{av}}=$ $1 / 3\left[g_{\|}+2 g_{\perp}\right]$. Complex exhibits $g_{\|}<2.3$, suggesting covalent characters of the copper-ligand bonding in this complex. The parameter $\mathrm{G}=g_{\|} 2.0582$, 2.0561 and 2.0323 respectively, shows the possibility of exchange interaction in the $\mathrm{Cu}(\mathrm{II})$ complex. The $\mathrm{G}$ values for the complex $(G>4)$ indicate that there is no direct copper-copper interaction in the solid state ${ }^{30}$. The $g_{\|} / \mathrm{A}_{\|}$is taken as an indication for the stereochemistry of the copper(II) complexes. Addison $^{31}$ has suggested that this ratio may be an empirical indication of the octahedral distortion geometry. The values higher than $148 \mathrm{~cm}$ are observed for octahedral distorted complexes. The value of $g_{\|} / \mathrm{A}_{\|}$quotient for the complex under investigation lies higher 148 $\mathrm{cm}$, indicating octahedral geometry around copper in this complex. The magnetic moment value for these complexes was found to be 1.56 B.M. per $\mathrm{Cu}$ ion ${ }^{30}$.

The absorption spectral bands of light green Ni(II) complexes exhibit three band in the ranges $945-935,712-642$ and 398-379 $\mathrm{nm}$, respectively shows three spin allowed transitions: ${ }^{3} \mathrm{~A}_{2 \mathrm{~g}}(\mathrm{~F}) \rightarrow{ }^{3} \mathrm{~T}_{2} \mathrm{~g}(\mathrm{~F}),{ }^{3} \mathrm{~A}_{2 \mathrm{~g}}(\mathrm{~F}) \rightarrow{ }^{3} \mathrm{~T}_{1} \mathrm{~g}(\mathrm{~F}),{ }^{3} \mathrm{~A}_{2} \mathrm{~g}(\mathrm{~F}) \rightarrow{ }^{3} \mathrm{~T}_{1} \mathrm{~g}(\mathrm{P})$ consistent with a typical $\mathrm{Ni}(\mathrm{II})$ in an octahedral environment ${ }^{32}$. The magnetic moment values for these complexes were found in the range 3.15-3.17 B.M expected ${ }^{32}$ for octahedral nickel complexes.

The electronic spectra of the cobalt(II) complexes gave three bands at 1012-971, 714645 and $425-388 \mathrm{~nm}$, which could be assigned to the transitions ${ }^{4} \mathrm{~T}_{1} \mathrm{~g}(\mathrm{~F}) \rightarrow{ }^{4} \mathrm{~T}_{2} \mathrm{~g}(\mathrm{~F})\left(v_{1}\right){ }^{4} \mathrm{~T}_{1} \mathrm{~g}$ $(\mathrm{F}) \rightarrow{ }^{4} \mathrm{~A}_{2} \mathrm{~g}(\mathrm{~F})\left(v_{2}\right)$ and ${ }^{4} \mathrm{~T}_{1} \mathrm{~g}(\mathrm{~F}) \rightarrow{ }^{4} \mathrm{~T}_{2} \mathrm{~g}(\mathrm{P})\left(v_{3}\right)$, respectively, suggesting an octahedral geometry around $\mathrm{Co}(\mathrm{II})$ ion $^{33}$. The complexes 5 and 6 show magnetic moment values in the range 2.8-3.1 B.M., which is smaller than the calculated value for two $\mathrm{Co}(\mathrm{II})$ ions in octahedral geometries and this may be due to anti-ferromagnetism between the two ioncenters. All complexes give satisfactory elemental analysis results as shown in Table 2.

\section{Synthesis of benzofuro- 2-carboxy- [4'-chlorophenyl] thiosemicarbazide}

benzofuran-2-carbohydrazide (4.58 g, $0.026 \mathrm{~mol})$ was dissolved in ethanol and this solution was added $p$-chlorophenyl isothiocyanate $(4.41 \mathrm{~g}, 0.026 \mathrm{~mol})$ in a 1:1 molar ratio containing few drop of concentrated $\mathrm{HCl}$. The solution was refluxed for $3 \mathrm{~h}$. The reaction mixture was cooled to room temperature and the solvent removed under reduced pressure by rotavapour until a solid product was formed and it was washed with cold ethanol and dried under vacuum. Melting point $151{ }^{\circ} \mathrm{C}$ and Yield $81 \%$. ${ }^{1} \mathrm{H}$ NMR $\left(300 \mathrm{MHz}, \mathrm{DMSO}-\mathrm{d}_{6}\right) \delta=6.45-7.65(\mathrm{~m}, 5 \mathrm{H}$, Ar-H benzofuran), 8.13 (s, Ar-H, Carbonyl Phenyl), 10.15 (s, 1x1H, NH of carbazide). ${ }^{13} \mathrm{C}$ NMR $\left(300 \mathrm{MHz}, \mathrm{DMSO}-\mathrm{d}_{6}\right) \delta=166.7(\mathrm{C}=\mathrm{O}), 158.4,150.0,149.1,130.5,129.4,124.7$, 123.3, 121.0, 114.6, 111.6, (Ar-C), UV-Vis (Nujol mul (nm)): $\lambda=370,420,480$. UV/vis $\left(1 \times 10^{-4}\right.$ mol, DMSO $): \lambda=360,390,445$. IR $(\mathrm{KBr}): v\left(\mathrm{~N}^{2} \mathrm{H}\right) 3245, v(\mathrm{C}=\mathrm{O}) 1720, v(\mathrm{~N}-\mathrm{N}) 1115$, $v(\mathrm{C}-\mathrm{C}) 760, v\left(\mathrm{C}=\mathrm{C}\right.$, aromatic) $1540, v\left(\mathrm{C}-\mathrm{H}\right.$, aromatic) $3040, v(\mathrm{NH}$, hydrazide $) 3155 \mathrm{~cm}^{-1}$.

\section{Synthesis of the metal complex $\left[\mathrm{Cu}_{2}\left(\mathrm{C}_{56} \mathrm{H}_{40} \mathrm{~N}_{10} \mathrm{Cl}_{2} \mathrm{O}_{16} \mathrm{~S}_{2}\right)\right]$ (1)}

A solution of divalent metal salt $\mathrm{CuCl}_{2} 2 \mathrm{H}_{2} \mathrm{O}(0.826 \mathrm{~g}, 4.845 \mathrm{mmol})$ in methanol $(8 \mathrm{~mL})$ was added to a hot solution $\left(75^{\circ} \mathrm{C}\right)$ of benzofuro-2-carboxy- [4'-chlorophenyl] thiosemicarbazide ligand (2.281 g, $5.116 \mathrm{mmol})$ and 2-nitrophenol (1.410 g, $10.137 \mathrm{mmol})$ in ethanol (25 $\mathrm{mL})$ and the reaction mixture was refluxed for $7 \mathrm{~h}$. The solution was concentrated under vacuum. The precipitate was filtered off, washed with methanol and dried under vacuum over anhydrous $\mathrm{CaCl}_{2}(1.06 \mathrm{~g}, 71 \%$ yield $)$. 
Conductance $4 \mathrm{~m}: 72 \Omega^{-1} \mathrm{~cm}^{2} \mathrm{~mol}^{-1}$. UV-Vis (Nujol mul (nm)): $\lambda=355,375,420,525$, 720 and 1155. IR (KBr): $v\left(\mathrm{~N}^{2} \mathrm{H}\right) 3272, v(\mathrm{C}=\mathrm{O}) 1720, v(\mathrm{~N}-\mathrm{N}) 1122, v(\mathrm{C}-\mathrm{C}) 760, v(\mathrm{C}=\mathrm{C}$, aromatic) 1540, v(C-H, aromatic) 3040, $v(\mathrm{NH}$, hydrazide) $3144, v(\mathrm{M}-\mathrm{N}) 425$,

Synthesis of the metal complex $\left[\mathrm{Ni}_{2}\left(\mathrm{C}_{56} \mathrm{H}_{40} \mathrm{~N}_{10} \mathrm{Cl}_{2} \mathrm{O}_{16} \mathrm{~S}_{2}\right)\right]$ (2)

A solution of divalent metal salt $\mathrm{NiCl}_{2} 6 \mathrm{H}_{2} \mathrm{O}(0.988 \mathrm{~g}, 4.156 \mathrm{mmol})$ in methanol $(12 \mathrm{~mL})$ was added to a hot solution $\left(75{ }^{\circ} \mathrm{C}\right)$ of benzofuro- 2-carboxy- [4'-chlorophenyl] thiosemicarbazide ligand $(2.281 \mathrm{~g}, 5.116 \mathrm{mmol})$ and 2-nitrophenol $(1.410 \mathrm{~g}, 10.137 \mathrm{mmol})$ in ethanol $(30 \mathrm{~mL})$ and the reaction mixture was refluxed for $8 \mathrm{~h}$. The solution was concentrated under vacuum. The precipitate was filtered off, washed with methanol and dried under vacuum over anhydrous $\mathrm{CaCl}_{2}$ (1.16 g, $78 \%$ yield).

Conductance $4 \mathrm{~m}: 09 \Omega^{-1} \mathrm{~cm}^{2} \mathrm{~mol}^{-1}$. UV-Vis(Nujol mul (nm)): $\lambda=255,275,320,525$, 720 and 1155. IR $(\mathrm{KBr}): v\left(\mathrm{H}_{2} \mathrm{O}\right) 3429, v\left(\mathrm{~N}^{2} \mathrm{H}\right) 3272, v(\mathrm{C}=\mathrm{O}) 1720, v(\mathrm{C}-\mathrm{C}) 770, v(\mathrm{C}=\mathrm{C}$, aromatic) 1544, $v(\mathrm{C}-\mathrm{H}$, aromatic) $3030, v(\mathrm{NH}$, hydrazide) $3140, v(\mathrm{~N}-\mathrm{N}) 1120, v(\mathrm{M}-\mathrm{N}) 422$, $v(\mathrm{M}-\mathrm{O}) 485 \mathrm{~cm}^{-1}$.

Synthesis of the metal complex $\left[\mathrm{Co}_{2}\left(\mathrm{C}_{56} \mathrm{H}_{40} \mathrm{~N}_{10} \mathrm{Cl}_{2} \mathrm{O}_{16} \mathrm{~S}_{2}\right)\right]$ (3)

A solution of divalent metal salt $\mathrm{CoCl}_{2} 6 \mathrm{H}_{2} \mathrm{O}(0.892 \mathrm{~g}, 3.749 \mathrm{mmol})$ in methanol $(10 \mathrm{~mL})$ was added to a hot solution $\left(75^{\circ} \mathrm{C}\right)$ of benzofuro-2-carboxy-[4'-chlorophenyl] thiosemicarbazide ligand $(2.281 \mathrm{~g}, 5.116 \mathrm{mmol})$ and 2-nitrophenol (1.410 g, $10.137 \mathrm{mmol})$ in ethanol $(28 \mathrm{~mL})$, and the reaction mixture was refluxed for $7.5 \mathrm{~h}$. The solution was concentrated under vacuum. The precipitate was filtered off, washed with methanol and dried under vacuum over anhydrous $\mathrm{CaCl}_{2}(1.30 \mathrm{~g}, 75 \%$ yield $)$.

Conductance $\Lambda \mathrm{m}: 15 \Omega^{-1} \mathrm{~cm}^{2} \mathrm{~mol}^{-1}$. UV-Vis(Nujol mul (nm)): $\lambda=260,272,325,520$, 724 and 1150. IR(KBr): $v\left(\mathrm{H}_{2} \mathrm{O}\right) 3340, v\left(\mathrm{~N}^{2} \mathrm{H}\right) 3260, v(\mathrm{C}=\mathrm{O}) 1780, v(\mathrm{~N}-\mathrm{N}) 1123, v(\mathrm{C}-\mathrm{C})$ 766, $v(\mathrm{C}=\mathrm{C}$, aromatic) $1543, v(\mathrm{C}-\mathrm{H}$, aromatic) $3033, v(\mathrm{NH}$, hydrazide $) 3150, v(\mathrm{M}-\mathrm{N}) 420$, $v(\mathrm{M}-\mathrm{O}) 500 \mathrm{~cm}^{-1}$.

Synthesis of the metal complex $\left[\mathrm{Cu}_{2}\left(\mathrm{C}_{56} \mathrm{H}_{36} \mathrm{~N}_{14} \mathrm{Cl}_{2} \mathrm{O}_{24} \mathrm{~S}_{2}\right)\right]$ (4)

A solution of divalent metal salt $\mathrm{CuCl}_{2} 2 \mathrm{H}_{2} \mathrm{O}(0.826 \mathrm{~g}, 4.845 \mathrm{mmol})$ in methanol $(8 \mathrm{~mL})$ was added to a hot solution $\left(75^{\circ} \mathrm{C}\right)$ of benzofuro- 2-carboxy- [4'-chlorophenyl] thiosemicarbazide ligand (2.281 g, $5.116 \mathrm{mmol})$ and 2, 3-dinitrophenol (1.891 g, $10.270 \mathrm{mmol})$ in ethanol $(25 \mathrm{~mL})$, the reaction mixture was refluxed for $7 \mathrm{~h}$. The precipitate was filtered off, washed with methanol and dried under vacuum over anhydrous $\mathrm{CaCl}_{2}(1.37 \mathrm{~g}, 73 \%$ yield $)$.

Conductance $\Lambda \mathrm{m}: 74 \Omega^{-1} \mathrm{~cm}^{2} \mathrm{~mol}^{-1}$. UV-Vis (Nujol mul (nm)): $\lambda=260,280,320,450$, 700, 1150. IR (KBr): v( $\left.\mathrm{H}_{2} \mathrm{O}\right) 3380, v\left(\mathrm{~N}^{2} \mathrm{H}\right) 3260, v(\mathrm{C}=\mathrm{O}) 1735, v(\mathrm{~N}-\mathrm{N}) 1146, v(\mathrm{M}-\mathrm{N}) 440$, $v(\mathrm{C}-\mathrm{C}) 755, v(\mathrm{C}=\mathrm{C}$, aromatic) $1540, v(\mathrm{C}-\mathrm{H}$, aromatic) $3040, v(\mathrm{NH}$, hydrazide $) 3145$,

Synthesis of the metal complex $\left[\mathrm{Ni}_{2}\left(\mathrm{C}_{56} \mathrm{H}_{36} \mathrm{~N}_{14} \mathrm{Cl}_{2} \mathrm{O}_{24} \mathrm{~S}_{2}\right)\right]$ (5)

A solution of divalent metal salt $\mathrm{NiCl}_{2} 6 \mathrm{H}_{2} \mathrm{O}(0.988 \mathrm{~g}, 4.156 \mathrm{mmol})$ in methanol $(12 \mathrm{~mL})$ was added to a hot solution $\left(75^{\circ} \mathrm{C}\right)$ of benzofuro- 2-carboxy- [4'-chlorophenyl] thiosemicarbazide ligand $(2.281 \mathrm{~g}, 5.116 \mathrm{mmol})$ and 2, 3-dinitrophenol $(1.891 \mathrm{~g}, 10.270 \mathrm{mmol})$ in ethanol (30 $\mathrm{mL}$ ) and the reaction mixture was refluxed for $8 \mathrm{~h}$. The solution was concentrated under vacuum. The precipitate was filtered off, washed with methanol and dried under vacuum over anhydrous $\mathrm{CaCl}_{2}(1.06 \mathrm{~g}, 72 \%$ yield $)$.

Conductance $4 \mathrm{~m}: 11 \Omega^{-1} \mathrm{~cm}^{2} \mathrm{~mol}^{-1}$. UV-Vis (Nujol mul (nm)): $\lambda=255,275,320$, 525, 720 and 1155. IR $(\mathrm{KBr}): v\left(\mathrm{H}_{2} \mathrm{O}\right) 3429, v\left(\mathrm{~N}^{2} \mathrm{H}\right) 3272, v(\mathrm{C}=\mathrm{O}) 1732, v(\mathrm{~N}-\mathrm{N}) 1122$, $v(\mathrm{C}-\mathrm{C}) 754, v(\mathrm{C}=\mathrm{C}$, aromatic) $1544, v(\mathrm{C}-\mathrm{H}$, aromatic $) 3044, v(\mathrm{NH}$, hydrazide $) 3144$, $v(\mathrm{M}-\mathrm{N}) 425, v(\mathrm{M}-\mathrm{O}) 490 \mathrm{~cm}^{-1}$. 
Synthesis of the metal complex $\left[\mathrm{Co}_{2}\left(\mathrm{C}_{56} \mathrm{H}_{36} \mathrm{~N}_{14} \mathrm{Cl}_{2} \mathrm{O}_{24} \mathrm{~S}_{2}\right)\right]$ (6)

A solution of divalent metal salt $\mathrm{CoCl}_{2} 6 \mathrm{H}_{2} \mathrm{O}(0.892 \mathrm{~g}, 3.749 \mathrm{mmol})$ in methanol $(10 \mathrm{~mL})$ was added to a hot solution $\left(75{ }^{\circ} \mathrm{C}\right)$ of benzofuro- 2-carboxy- [4'-chlorophenyl] thiosemicarbazide ligand $(2.281 \mathrm{~g}, 5.116 \mathrm{mmol})$ and 2, 3-dinitrophenol (1.891 g, 10.270 $\mathrm{mmol})$ in ethanol $(28 \mathrm{~mL})$ and the reaction mixture was refluxed for $7.5 \mathrm{~h}$. The precipitate was filtered off, washed with methanol and dried under vacuum over anhydrous $\mathrm{CaCl}_{2}(1.54 \mathrm{~g}, 77 \%$ yield $)$.

Conductance $4 \mathrm{~m}: 16 \Omega^{-1} \mathrm{~cm}^{2} \mathrm{~mol}^{-1}$. UV-Vis (Nujol mul (nm)): $\lambda=255,280,330$, 451, 680 and 1140. IR $(\mathrm{KBr}): v\left(\mathrm{H}_{2} \mathrm{O}\right) 3311, v\left(\mathrm{~N}^{2} \mathrm{H}\right) 3260, v(\mathrm{C}=\mathrm{O}) 1722, v(\mathrm{~N}-\mathrm{N}) 1123$, $v(\mathrm{C}-\mathrm{C}) 750, v(\mathrm{C}=\mathrm{C}$, aromatic $) 1539, v(\mathrm{C}-\mathrm{H}$, aromatic) 3043, $v(\mathrm{NH}$, hydrazide $) 3140$, $v(\mathrm{M}-\mathrm{N}) 470, v(\mathrm{M}-\mathrm{O}) 510 \mathrm{~cm}^{-1}$.

Synthesis of the metal complex $\left[\mathrm{Cu}_{2}\left(\mathrm{C}_{56} \mathrm{H}_{32} \mathrm{~N}_{18} \mathrm{Cl}_{2} \mathrm{O}_{32} \mathrm{~S}_{2}\right)\right]$ (7)

A solution of divalent metal salt $\mathrm{CuCl}_{2} 2 \mathrm{H}_{2} \mathrm{O}(0.826 \mathrm{~g}, 4.845 \mathrm{mmol})$ in methanol $(8 \mathrm{~mL})$ was added to a hot solution $\left(75{ }^{\circ} \mathrm{C}\right)$ of benzofuro- 2-carboxy- [4'-chlorophenyl] thiosemicarbazide ligand $(2.281 \mathrm{~g}, 5.116 \mathrm{mmol})$ and 2, 3, 4-trinitrophenol (2.342 g, 10.211 mmol) in ethanol $(25 \mathrm{~mL})$, the reaction mixture was refluxed for $7 \mathrm{~h}$. The precipitate was filtered off, washed with methanol and dried under vacuum over anhydrous $\mathrm{CaCl}_{2}(1.28 \mathrm{~g}$, $75 \%$ yield).

Conductance $4 \mathrm{~m}: 79 \Omega^{-1} \mathrm{~cm}^{2} \mathrm{~mol}^{-1}$. UV-Vis (Nujol mul (nm)): $\lambda=260,331,467,652$ and 1061. IR (KBr): v( $\left.\mathrm{H}_{2} \mathrm{O}\right) 3406, v\left(\mathrm{~N}^{2} \mathrm{H}\right) 3286, v(\mathrm{C}=\mathrm{O}) 1735, v(\mathrm{~N}-\mathrm{N}) 1145, v(\mathrm{C}-\mathrm{C}) 745$, $v(\mathrm{C}=\mathrm{C}$, aromatic $) 1533, v(\mathrm{C}-\mathrm{H}$, aromatic) 3044, $v(\mathrm{NH}$, hydrazide $) 3145, v(\mathrm{M}-\mathrm{N}) 455$.

Synthesis of the metal complex $\left[\mathrm{Ni}_{2}\left(\mathrm{C}_{56} \mathrm{H}_{32} \mathrm{~N}_{18} \mathrm{Cl}_{2} \mathrm{O}_{32} \mathrm{~S}_{2}\right)\right]$ (8)

A solution of divalent metal salt $\mathrm{NiCl}_{2} 6 \mathrm{H}_{2} \mathrm{O}(0.988 \mathrm{~g}, 4.485 \mathrm{mmol})$ in methanol $(12 \mathrm{~mL})$ was added to a hot solution $\left(75^{\circ} \mathrm{C}\right)$ of benzofuro- 2-carboxy- [4'-chlorophenyl] thiosemicarbazide ligand $(2.281 \mathrm{~g}, 5.116 \mathrm{mmol})$ and 2, 3, 4-trinitrophenol (2.342 g, 10.211 $\mathrm{mmol})$ in ethanol $(30 \mathrm{~mL})$ and the reaction mixture was refluxed for $8 \mathrm{~h}$. The solution was concentrated under vacuum. The precipitate was filtered off, washed with methanol and dried under vacuum over anhydrous $\mathrm{CaCl}_{2}(1.06 \mathrm{~g}, 74 \%$ yield $)$.

Conductance $4 \mathrm{~m}: 12 \Omega^{-1} \mathrm{~cm}^{2} \mathrm{~mol}^{-1}$. UV-Vis (Nujol mul (nm)): $\lambda=255,275,320,525$, 720 and 1155. IR (KBr): $v\left(\mathrm{H}_{2} \mathrm{O}\right) 3429(\mathrm{br}), v\left(\mathrm{~N}^{2} \mathrm{H}\right) 3272, v(\mathrm{C}=\mathrm{O}) 1690, v(\mathrm{~N}-\mathrm{N}) 1132, v(\mathrm{C}-\mathrm{C})$ $760, v(\mathrm{C}=\mathrm{C}$, aromatic $) 1533, v(\mathrm{C}-\mathrm{H}$, aromatic) $3053, v(\mathrm{NH}$, hydrazide $) 3133, v(\mathrm{M}-\mathrm{N}) 425$, $v(\mathrm{M}-\mathrm{O}) 490 \mathrm{~cm}^{-1}$.

Synthesis of the metal complex $\left[\mathrm{Co}_{2}\left(\mathrm{C}_{56} \mathrm{H}_{32} \mathrm{~N}_{18} \mathrm{Cl}_{2} \mathrm{O}_{32} \mathrm{~S}_{2}\right)\right]$ (9)

A solution of divalent metal salt $\mathrm{CoCl}_{2} 6 \mathrm{H}_{2} \mathrm{O}(0.892 \mathrm{~g}, 3.749 \mathrm{mmol})$ in methanol (10 $\mathrm{mL})$ was added to a hot solution $\left(75^{\circ} \mathrm{C}\right)$ of benzofuro- 2-carboxy- [4'-chlorophenyl] thiosemicarbazide ligand $(2.281 \mathrm{~g}, 5.116 \mathrm{mmol})$ and 2, 3, 4-trinitrophenol $(2.342 \mathrm{~g}$, $10.211 \mathrm{mmol})$ in ethanol $(28 \mathrm{~mL})$, the reaction mixture was refluxed for $7.5 \mathrm{~h}$. The precipitate was filtered off, washed with methanol and dried under vacuum over anhydrous $\mathrm{CaCl}_{2}(1.35 \mathrm{~g}, 76 \%$ yield $)$.

Conductance $\Lambda \mathrm{m}: 18 \Omega^{-1} \mathrm{~cm}^{2} \mathrm{~mol}^{-1}$. UV-Vis (Nujol mul (nm)): $\lambda=265,280,340$, $489,636,1051$. IR $(\mathrm{KBr}): v\left(\mathrm{H}_{2} \mathrm{O}\right) 3419, v\left(\mathrm{~N}^{2} \mathrm{H}\right) 3277, v(\mathrm{C}=\mathrm{O}) 1710, v(\mathrm{~N}-\mathrm{N}) 1120, v(\mathrm{C}-$ C) $750, v(\mathrm{C}=\mathrm{C}$, aromatic) $1539, v(\mathrm{C}-\mathrm{H}$, aromatic) $3044, v(\mathrm{NH}$, hydrazide $) 3144, v(\mathrm{M}-$ N) $460, v(\mathrm{M}-\mathrm{O}) 525 \mathrm{~cm}^{-1}$. 


\section{Conclusion}

The analytical data showed the presence of two metal ion molecule and suggested a binuclear structure for the complexes $\left[\mathrm{M}_{2}(\mathrm{HL})\right]$. The spectroscopical studies of the metal ion complexes are in the favor of a six coordinate octahedral geometry of the complexes.

\section{References}

1. Schiff H, Ann., 1869, 150(2), 193-200; DOI:10.1002/jlac.18691500206

2. Etting C, Ann., 1840, 35, 241.

3. Chaston S H H, Livingstone S E, Lockyer T N and Shannon J S, Aust J Chem., 1965, 18(10), 1539-1548; DOI:10.1071/CH9651539

4. Lindoy L F, Livingstone S E and Lokcyer T N, Aust J Chem., 1966, 19(8), 13911400; DOI:10.1071/CH9661391

5. Dutt N K and Nag K, J Inorg Nucl Chem., 1968, 30(9), 2493-2499; DOI:10.1016/0022-1902(68)80263-5

6. Iftikhar K, Sayeed A M and Ahmad N, Ind J Chem., 1968, 25A, 589.

7. Zelentsov V V, Russ J Inorg Chem., 1962, 7, 670.

8. Kumar G, Devi S and Johari J, J Chem., 2012, 9(4), 2255-2560; DOI:10.1155/2012/956812

9. Kalinnikov V T, Zalentsov V V, Kuzmichiva N and Aminov T G, Russ J Inorg Chem., 1970, 15, 341.

10. Poddar S N, Dev D, Haldar J and Nathsarkar S C, J Ind Chem Soc., 1970, 47, 743.

11. Lee C C, Shyamal A and Theriot L, J Inorg Chem., 1971, 10(8)B, 1669-1673.

12. Kumar G, Kumar D, Devi S, Johari R and Singh C P, Eur J Med Chem., 2010, 45(7), 3056-3062.

13. Kuge Y and Yamada S, Bull Chem Soc (Japan), 1972, 45(3), 799-802; DOI:10.1246/bcsj.45.799

14. Lindoy L F, Moody W E and Taylor D, Inorg Chem., 1977, 16(8), 1962-1968; DOI:10.1021/ic50174a027

15. Boge E M, Freyberg D P, Kokot E, Mockler G M and Sinn E, Inorg Chem., 1977, 16(7), 1655-1660; DOI:10.1021/ic50173a016

16. Dilli S and Patsalides E, J Chromatgr A, 1977, 134(2), 477-482; DOI:10.1016/S00219673(00)88547-7

17. Ansary M S and Ahmad N, Acta Chem Acad Scient Hungaricae, 1979, 92, 27.

18. Tripathy M, Singh R V and Tandon J P, Indian J Chem., 1981, 20A, 90.

19. Kumar G, Devi S, Johari R and Kumar D, Eur J Med Chem., 2012, 52, 269-274; DOI:10.1016/j.ejmech.2012.03.025

20. Prasad R N, Mathur M and Upadhayay A, J Indian Chem Soc., 2007, 84(12), 1202-1204.

21. Oxley J, Smith J, Brady J, Dubnikova F, Kosloff R, Zeiri L and Zeiri Y, Appl Spectr., 2008, 62(8), 906-915; DOI:10.1366/000370208785284420.

22. Shakir M, Nasman O S M and Varkey S P, Polyhedron, 1996, 15(2), 309-314; DOI:10.1016/0277-5387(95)00189-Y

23. Shakir M, Islam K S, Mohamed A K, Shagufa M and Hasan S S, Transit Met Chem., 1999, 24(5), 577-580; DOI:10.1023/A:1006900222831

24. Chandra S and Kumar R, Transit Met Chem., 2004, 29(3), 269-275; DOI:10.1023/B:TMCH.0000020359.84853.72

25. Rana V B, Singh D P, Singh P and Teotia M P, Transit Met Chem., 1982, 7(3), 174177; DOI:10.1007/BF01035836 
26. Gunthkal M S, Goudal T R and Patil S A, Oriental J Chem., 2000, 16, 151-161.

27. Kulkarni A, Patil S A and Badami P S, Eur J Med Chem., 2009, 44(7), 2904-2912; DOI:10.1016/j.ejmech.2008.12.012

28. Shakir M, Chingsubam P, Chishti H TN, Azim Y and Begum N, Indian J Chem., 2004, 43A, 556-561.

29. Niasari M S, Bazarganipour M, Ganjali M R, Norouzi P, Transition Met Chem., 2007, 32(1), 9-15; DOI:10.1007/s11243-006-0109-y

30. Chandra S, Gupta L K, Spectrochim Acta A: Mole Biomole Spectro., 2004, 60(12), 2767-2774; DOI:10.1016/j.saa.2004.01.015

31. Boghaei D M and Gharagozlou M, Spectrochim Acta A: Mole Biomole Spectro., 2007, 67(3-4), 944-949; DOI:10.1016/j.saa.2006.09.012

32. Nakamoto K and McCarthy P J, Spectroscopy and structure of metal chelate compounds, John-Wiley and sons Inc., New York, 1968.

33. Nagesh G Y and Mruthyunjayaswamy B H M, J Mole Struct., 2015, 1085, 198-206; DOI:10.1016/j.molstruc.2014.12.058 